\title{
CORELLA HALLI N.SP., A NEW ASCIDIAN FROM THE ENGLISH CHANNEL
}

\author{
By Patricia Kott, M.Sc. ${ }^{1}$ \\ From the Plymouth Laboratory
}

\section{(Text-fig. I)}

In September I950 Dr H. W. Parker of the British Museum (Natural History) kindly sent me a specimen of an ascidian collected by the yacht, Manihine, for identification. This has proved to belong to an unnamed species of the genus Corella, here described as $C$. halli. The unique type specimen was obtained from dredgings on a shingle bottom at 35 fathoms, Io miles WSW. of the Casquets in the English Channel, 30 August 1950 (Manihine, Station no. 8I).

External features. The animal (Fig. IA) is enclosed in a transparent test, laterally flattened, circular, of $4 \mathrm{~mm}$. diameter and fixed basally to pieces of sand; there is no stalk. The branchial aperture is terminal anteriorly; the atrial aperture is also anterior and dorsal to the branchial aperture. Both apertures are sessile.

Mantle. The animal inside the test is $2 \mathrm{~mm}$. in diameter. The mantle musculature is weakly developed (Fig. I B): there is one circular muscle band around the base of each siphon, five narrow muscle bands run transversely across the anterior aspect of the body ventral to the branchial siphon, another five bands radiate from each side of the branchial siphon and two similar bands radiate from the atrial siphon. In the postero-dorsal corner of the left side of the body there are seven narrow bands of muscle set obliquely.

The atrial siphon is bordered by six small pointed lobes and the branchial siphon has eight similar lobes.

Tentacles. The branchial tentacles are simple; there are fifteen long slender tentacles alternating with the same number of very short tentacles.

The dorsal tubercle (Fig. IC) is anterior and to the left of the neural ganglion and slightly on the left side of the peritubercular prebranchial space. It is of the usual semicircular form typical of this genus, with the concavity directed anteriorly and to the right.

Dorsal lamina (Fig.I C). Languets representing the dorsal lamina are short, broad laterally, and flattened antero-posteriorly. Terminally they come to a sudden small point and are not long and tapering as are the dorsal languets of C. parallelogramma (Müll.). In this specimen there are eleven languets.

\footnotetext{
${ }^{1}$ C.S.I.R.O. Fisheries Division, Cronulla, Australia.
} 
Branchial sac. The form and arrangement of the stigmata (Fig. ID) are similar to those found in immature specimens of $C$. parallelogramma: the stigmata are arranged in pairs in fourteen transverse rows. There are twenty longitudinal vessels on each side of the body supported by papillae between each of the stigmata; intermediate transverse vessels are present and these occasionally carry a small papilla between two successive longitudinal vessels. The anterior and posterior corners of the stigmata of each pair are turned inwards
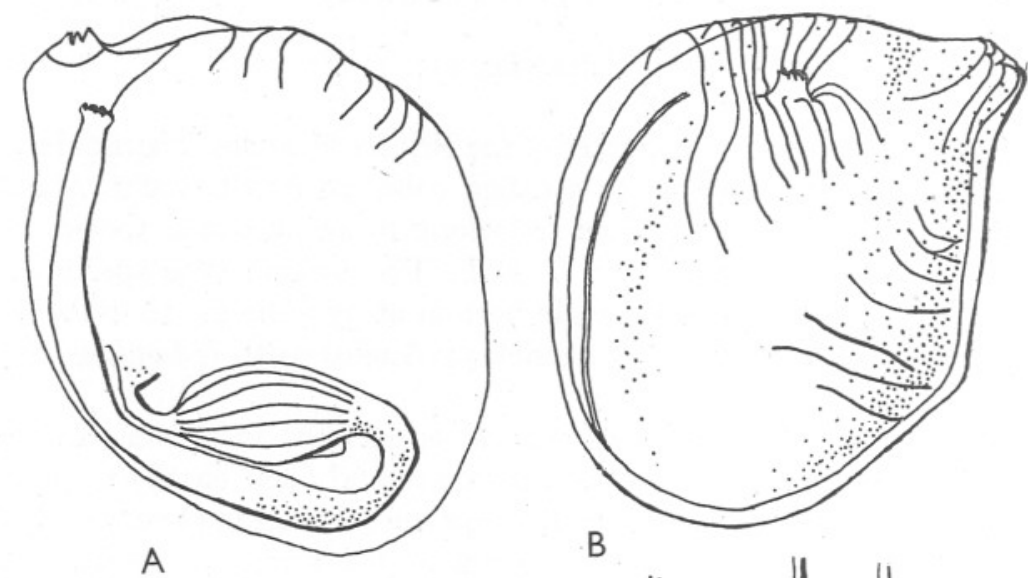

A

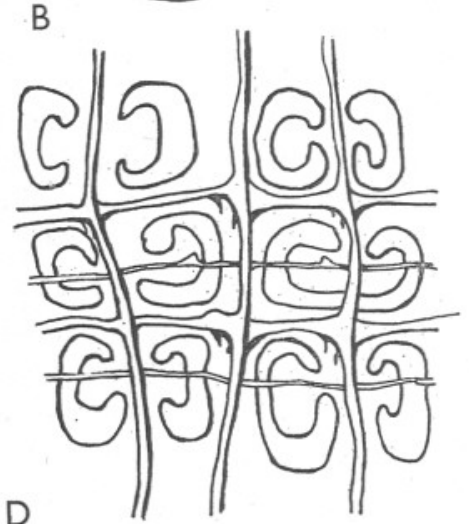

Fig. I. Corella halli $\mathrm{n}$.sp. Type specimen. A, zooid from the right side showing alimentary canal, $\times 24$; B, zooid from the left side showing mantle musculature, $\times 24$; C, region of the neural ganglion showing the anterior part of the dorsal limina, the dorsal tubercle and neural ganglion, $\times 72 ; \mathrm{D}$, part of the posterior end of the branchial sac showing one pair of the stigmata joined in the horizontal plane, $\times 72$.

and in the posterior part of the sac there are still a few stigmata joined in the horizontal plane (Selys-Longchamps, I90I, pl. xxiv, fig. 7).

Alimentary canal (Fig. I A). The oesophagus is short and narrow and opens into a spindle-shaped stomach with twelve longitudinal furrows and a short pyloric caecum. The anal opening is fringed by eight rounded lobes. The alimentary canal is completely on the right side of the body. 
Gonads. Gonad cells are present and spread diffusely over and between the loop of the alimentary canal as in other species of this genus.

Relations. In the form of its branchial sac this specimen might be identified as a young specimen of $C$. parallelogramma (Müll.); it is here described as a new species, however, since there are certain distinctive features which do not occur in $C$. parallelogramma and since the presence of gonad cells indicate a mature form. The species is distinguished from $C$. parallelogramma by the following characters: the tentacles are of two orders, long alternating with very short; the alimentary canal is on the right-hand side of the body, whereas in the young forms of $C$. parallelogramma which have been described the alimentary canal is posterior to the branchial sac; the stomach is longer and more spindle-shaped and there are lobes present around the anus while the anal borders of several specimens of $C$. parallelogramma examined are smooth; the languets of the dorsal lamina are fewer. Unless further collection and study of the development of $C$. parallelogramma indicates that this specimen is merely an individual variant of a young form, the species is particularly interesting and shows a primitive condition of the branchial sac in the evolution from straight to coiled stigmata. It is natural to assume that there may be some species in the transition stage which the form described above would represent; a stage in the evolution of Corella which is recapitulated in the life history of the more highly specialized C. parallelogramma.

Corella halli n.sp. is named after Major H. W. Hall, M.C., who has made his yacht Manihine available to the British Museum for collecting; the specimen comes from the Manihine collections of the British Museum (Natural History) where it is deposited under the type number B.M. I950.9.2I.I. My thanks are due to Dr H. W. Parker for giving me the opportunity of describing it.

\section{BIBLIOGRAPHY}

Alder, J. \& Hancock, A., 1907. The British Tunicata. [Vol. II, pp. 25, 28, 3I.]

ARNBACK-Christie-LINDE, A., I934. Northern and Arctic invertebrates in the collection of the Swedish State Museum. XII: Tunicata. 4. Cionidae, Ascidiidae, Agnesiidae, Rhodosomatidae. K. Svenska Vet.-Akad. Handl., Ser. 3, Bd. xIII, 9I pp. [p. 72.]

Berrill, N. J., I950. The Tunicata, Ray Soc., No. I33. [p. I49.]

HANCOCK, A., I870. On the larval state of Molgula; with description of several new species of simple ascidians. Ann. Mag. Nat. Hist., Ser. 4, Vol. vI, pp. 352-68.

HARANT, H., I93I. Contribution à l'histoire naturelle des ascidies et de leur parasites. Ann. Inst. Océan. Monaco, T. viII, pp. 23I-389. [p. 319.]

HARTMEYER, R., I924. Ascidiacea. II. Zugleich eine Übersicht über die arktische und boreale Ascidienfauna auf tiergeographischer Grundlage. Dan. Ingolf Exped., Vol. II, pt. 7, 275 pp. [p. Io.]

KuPfFER, C. W. voN, I875. Die Expedition zur physikalisch-chemischen und biologischen Untersuchung der Nordsee im Sommer 1872. VII. Tunicata. Fahresb. Komm. wiss. Unt. deutschen Meere Kiel, Jhrg. 2, pp. 197-228. [p. 214.] 
MÜLleR, O. F., I776. Zoologiae Danicae Prodromus. Copenhagen. [p. 226.]

Selys-Longchamps, M. DE, I9or. Étude du dévèloppement de la branchie chez Corella, avec une note sur la formation des protostigmates chez Ciona et Ascidiella. Arch. Biol., T. xvII, pp. 673-7II.

- I914. Evolution des stigmates branchiaux chez les Ascidies du genre Corella. Ann. Soc. Malacol. Belg., T. xLvIII, pp. I27-39.

Thompson, H., 1932. The Tunicata of the Scottish area. Their classification, distribution and ecology. Part III. Sedentary Tunicata (contd.). Order Diktyobranchia. Scot. Fish. Sci. Invest., No. 2, 42 pp. [p. 6.]

Traustedt, I883. Die einfachen Ascidien (Ascidiae simplices) des Golfes von Neapel. Mitt. Zool. Stat. Neapel, Vol. rv, pp. 448-88. [p. 452.] 